\title{
Spatial Behaviour and Activity Patterns of the Water Shrew Neomys fodiens in the Field
}

\author{
Jean-Pierre LARDET
}

\begin{abstract}
Lardet J.-P., 1988: Spatial behaviour and activity patterns of the water shrew, Neomys fodiens in the field. Acta theriol., 33, $21: 293-303$ [With 1 Table \& 3 Figs.].

Ten radioactive tracking sessions of individual European water shrews Neomys fodiens (Pennant, 1771) were done in order to compare water shrews with terrestrial shrews, such as Crocidura russula (Hermann, 1780) and Sorex coronatus Millet, 1828. Activity patterns, space use and home range size were studied. Each tracking session lasted 24 hours and the sessions were made between April and December from 1982 to 1985 . Water shrews were active for 12 hours a day, $(50.0 \pm 10.4 \%$ of 24 hours; $n=10$ ) without seasonal variations. Neomys fodiens were more active than Crocidura russula and less active than Sorex coronatus, probably because of different energy requirements. Activity was mainly confined to the stream, with an important concentration of the activity in muddy, rather than gravel, parts of the stream. This was probably because prey were more accessible in muddy parts. Between April and September, the home range sizes (as determined from the 24-hour sessions) were $207 \pm 93 \mathrm{~m}^{2}(n=6)$ for both males and females. From October to December, the values were $106 \pm 45 \mathrm{~m}^{2}(n=4)$ for males and females. These values are similar to those of Crocidura russula and smaller than the area covered by Sorex coronatus. Food availability and abundance are probably important factors which explain the relatively smaller home range of water shrews.
\end{abstract}

[Institut de Zoologie, Bâtiment de Biologie, Université de Lausanne, 1015 Lausanne, Switzerland].

\section{INTRODUCTION}

For small mammals, much research on home range has been made using the capture-mark-recapture (CMR) method. This method creates many ways to calculate the size of the home range (Stickel, 1954; review in Van Winkle, 1975). Generally, this method assumes that food is distributed homogenous and also it assumes a normal distribution of the trapping data. If such conditions do not exist, one must select a different model, such as that of Don \& Rennolls (1983), which includes the idea of certain points i.e. nests, food patches or other clumped resources which have a biological attraction for the animals.

It is interesting to compare the effects of food distribution on the home range size and activity distribution of shrews. Since there are both terrestrial and semiaquatic species one might except that differences in the foraging activities of a terrestrial Sorex species and the 
semiaquatic Neomys fodiens (Churchfield, 1984a) could influence the home range size. Although it is heavier, Neomys fodiens has a smaller home range (Van Bemmel \& Voesenek, 1984; CMR data), than Sorex minutus and $S$. araneus (Croin Michielsen, 1966).

CMR data, however, do not provide much information on the spatial behaviour of animals. To examine how an animal utilises its environment, it is necessary: to know how much time it spends at different parts of the home range. To date, the only available data on the activity of water shrews in the field are those of Schloeth (1980) and Illing et al. (1981). However, time budgets for Neomys fodiens were not cbtained in either of these studies, due to the techniques applied. Radioactive tracking can help to determine time budgets and has been used extensively for European shrews, by Genoud \& Vogel (1981) and Ricci \& Vogel (1984) on Crocidura russula, by Genoud (1984) on Sorex coronatus and by Khlyap $(1980,1983)$ on $S$. arcticus and $S$. araneus.

During a study on the energy strategy of Neomys fodiens (Lardet, 1987), radioactive tracking was carried out to determine home range size and activity patterns. The results are presented in this paper. My aims were to compare the behaviour of Neomys fodiens with terrestrial shrews species and to demonstrate the influence of the semiaquatic nature of Neomys on its activity and home range size. Time budgets of freeliving animals will be described and energy requirements calculated in the field (Lardet, 1987, in prep.), using methods proposed by Baar \& Fleharty (1976) and Travis (1982).

\section{MATERIAL AND METHODS}

\subsection{Study Area}

Field studies were carried out along a small stream of the western Swiss "Plateau". This site has previously bcen described by Weissenberger et al. (1983). Within the study area, the stream has a mean depth of $30 \mathrm{~cm}$. Populations of water shrews have been studied at this site for several years (Weissenberger ct al., 1983; Lardet \& Vogel, 1985) using the CMR technique.

\subsection{Rad oscive Tracking Sessions}

The tracking sessions were performed from 1982 and 1985, between April and December. Animals were captured in Longworth traps baited with meat. After trapping, a selected animal was marked with a metal ear tag bearing a radioactive piece of tantalium (Ta-182), with an activity of 200 to $600 \mu \mathrm{Ci}$. It could be located from a distance of approximately 10 metres, depending on its position (above or below ground). After release, the animal was detected with scintillation counters (Mini Instruments Ltd.). Its position was recorded at two minute inter- 
vals. Reference points were taken from numbered sticks placed along the stream. Each tracking session lasted 24 hours (the first period of activity was not included), during which time all activities were dictated onto a portable tape-recorder. At the end of the session, the animal was again trapped to recover the tag.

During each period of tracking, the following environmental data were recorded at three-hour intervals: air temperature $(50 \mathrm{~cm}$ above the ground level), water temperature (on the bottom of the stream) and soil temperature (at a depth of $10 \mathrm{~cm}$ ). These were measured, using a tele-thermometer (YSI 42, Kontron Analytic, Zürich) fitted with suitable probes.

The position of the tracked shrews were reported on a reference grid and the spatial behaviour of the animals was analyzed by a computer program, which calculated: (1) the size of the area used (for the purpose of the present study, the home range was defined as being that area used by a shrew for a period of 24 hours, in relation to the energy requirements of the individuals). The area is given by the number of one metre-squares crossed by the animal during the 24-hour period, (2) the total distance travelled, (3) the length of stream covered, (4) the time spent in activity in each square, (5) an index of aggregation, which is the ratio between the mean and the variance of the activity patterns (previously calculated) in each square of the area used. If this ratio is larger than one, activity is assumed to be concentrated.

Following Adams \& Davis (1967), the programme was adapted to construct a three-dimensionnal histogram showing how the animal used particular parts of the home range.

\section{RESULTS}

\subsection{Influence of Temperature}

Six mature adults (two males and four females) and one juvenile male were studied. Three individuals were tracked twice within an interval of several weeks. The others were tracked only once, because they were not trapped again. Tracking sesions were made during the reproductive months (April to September) and the autumn (October to December). No data are available for the period of January to March, since all attempts to catch shrews failed.

Soil temperature (since the animals usually moved underground) did not appear to influence the behaviour of Neomys fodiens. For example, in the case of activity (Fig. 1) the slope of the regression line did not significantly differ from zero $(p>0.05)$. Thereafter, the monthly values were plotted together in two groups: the reproductive season, with the results of April to September (mean \pm SD: $48.9 \pm 8.7 \%$ of $24 h, n=6$ ) and autumn (October to December: $51.6 \pm 13.8 \%, n=4$ ). Since this difference was not significant (Student t-test, $p>0.05$ ), the values were pooled to determine the mean (Table 1). None of the other values (except the home range size) differed significantly (Table 1). 


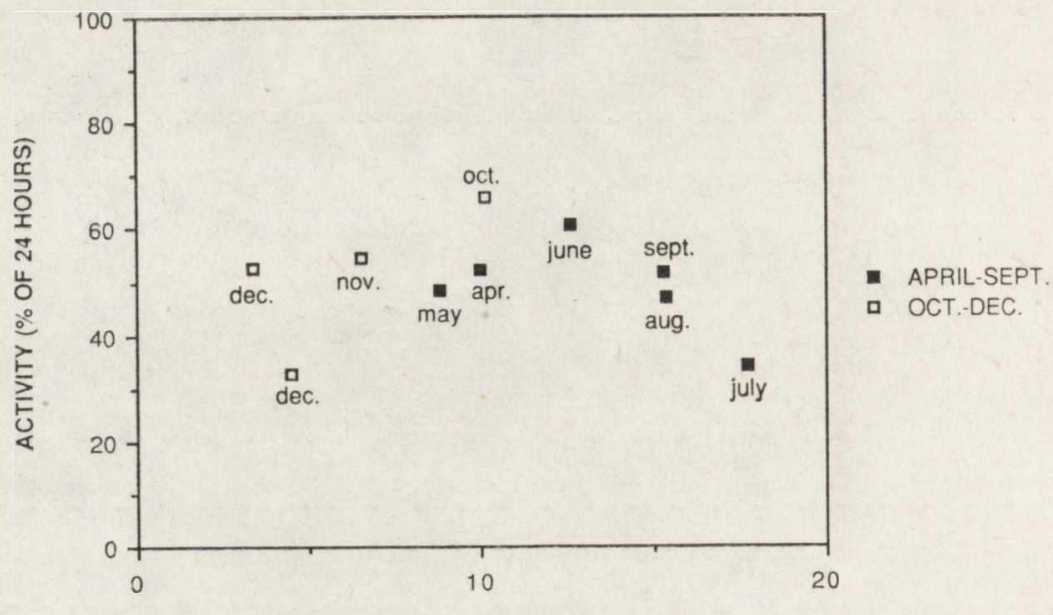

SOIL TEMPERATURE AT - $10 \mathrm{CM}\left({ }^{\circ} \mathrm{C}\right)$

Fig. 1. Activity (in \%) of Neomys fodiens during 24-hour tracking periods, in relation to soil temperature.

Table 1

Behavioral parameters of Neomys fodiens (24-hour tracking sessions). Min. and max. indicate minimum and maximum values, $n$ the number of observations.

\begin{tabular}{lcccr}
\hline Behavioral parameter & mean \pm SD & min. & max. & $n$ \\
\hline Activity $(\%$ of $24 \mathrm{~h}$ ) & $50.0 \pm 10.4$ & 32.8 & 66.1 & 10 \\
Number od activity periods & $8.4 \pm 3.0$ & 5 & 15 & 10 \\
Duration of an average period & & 11 & 511 & 10 \\
$\quad$ of activity & $98.2 \pm 36.9$ & 12 & 209 & 10 \\
of rest (min) & $87.3 \pm 22.5$ & 16.3 & 47.9 & 10 \\
Diurnal activity (min/h) & $27.0 \pm 9.7$ & 19.5 & 55.2 & 10 \\
Nocturnal activity (min/h) & $35.3 \pm 10.2$ & 101 & 373 & 6 \\
Home range size (m ${ }^{2}$ r & & 77 & 173 & 4 \\
$\quad$ reproductive season & $207 \pm 93$ & 23 & 99 & 10 \\
$\quad$ non-reproductive season & $106 \pm 45$ & 401 & 1121 & 10 \\
Travelled length of stream (m) & $49 \pm 25$ & 4.8 & 68.8 & 10 \\
Total travelled distance (m) & $717 \pm 283$ & & & \\
Index of aggregation & $23.8 \pm 19.3$ & &
\end{tabular}

\subsection{Activity}

The activity patterns of the tracked shrew were polyphasic (Fig. 2). The shrews had a mean activity of 12 hours per day (Table 1), with an average of $8.4 \pm 3.0$ activity periods. An average activity period lasted about 1.5 hours, which was similar to a resting period. Shrews were active both night $(35.3 \pm 10.2 \mathrm{~min} / \mathrm{h}, n=10)$ and day $(27.0 \pm 9.7 \mathrm{~min} / \mathrm{h}$, $n=10$ ). The difference was not significant ( $t$-test, $p>0.05)$. Tracking data 


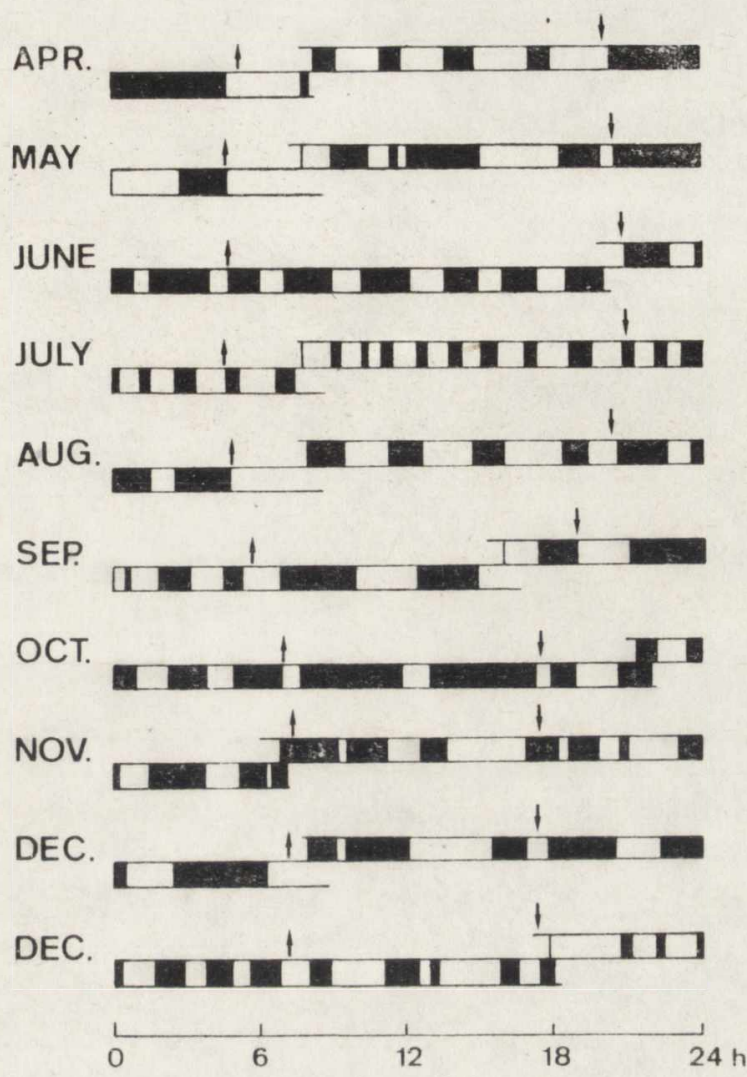

Fig. 2. Actograms of 10 radioactive tracking sessions of Neomys fodiens. The arrows indicate sunrise $(\uparrow)$ and sunset $(\downarrow)$. Periods of activity are shaded.

showed that activities of water shrews were mainly confined to the stream and its banks, although occasional "forays" into a nearby woodland were also observed. Usually, an animal spent most of its inactive time in one main nest. Secondary nests ( $n=1$ to 4$)$ were also used. All nests were underground, sometimes in old tree stumps, but always above the highest level of the stream.

Activity patterns were strongly concentrated along the stream: the index varied from 4.8 to 68.8 (Table 1). In the case shown in Figure 3 , for a 24-hour period, the tracked shrew spent most of its activity in five parts of its home range. These sites surrounded the nest (in this case the fundation of a farm building) and included four separate foraging sites. The shrew moved from one site to another, using rodent runs inside the banks.

Direct observations on the foraging behaviour of the tracked shrew showed that dives lasted 10 to 20 seconds. Prey was eaten on the bank. Underwater foraging was done mainly where there were muddy banks. 


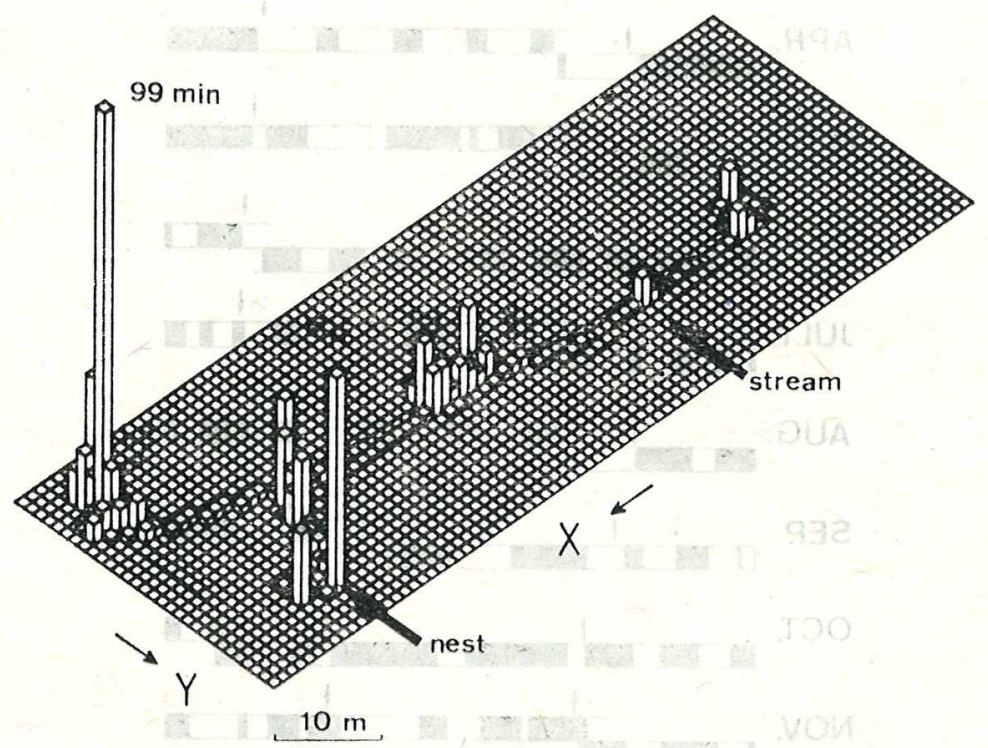

Fig. 3. Area covered during a 24-hour tracking session (in May 1984) by a male water shrew.

\subsection{Home Range Size}

Male and female range size did not differ (Mann-Whitney $U$ test, $p>0.5)$ during both the reproductive $(U=1, n=6)$ and the non-reproductive $(U=1, n=4)$ seasons. During the reproductive season, water shrews' range sizes were significantly greater $\left(207 \pm 93 \mathrm{~m}^{2}, n=6\right)$ than during the autumn $\left(106 \pm 45 \mathrm{~m}^{2}, n=4\right)$ (Mann-Whitney $U$ test, $U=2.0$, $p<0.05)$. Within their range, animals travelled a mean distance of $717 \pm$ $\pm 283 \mathrm{~m}(n=10)$. This included a stream $49 \pm 25 \mathrm{~m}(n=10)$ long (Table 1).

The home ranges of the three Neomys fodiens tracked twice within several weeks did not change. They only shifted a few metres, with animals foraging in the same places. Shrews used different nests during subsequent tracking sessions. The home ranges of individuals tracked during the same year overlapped.

\section{DISCUSSION}

\subsection{Season}

It was not possible to track shrews during the months of January, February and March, because no animals were trapped. Several authors (Dehnel, 1950; Price, 1953; Shillito, 1963b; Churchfield, 1984b; Weissenberger et al., 1983; Lardet \& Vogel, 1985) observed the same scarcity 
of $N$. fodiens during this period of the year. Therefore, it was assumed that Neomys moved away from its normal area (Shillito, 1963b; Lardet \& Vogel, 1985) during the winter period. It also seems to be more active below the ground (Churchfield, 1984b).

Home range size was the only parameter studied which fluctuated on a seasonal basis. It increased during the reproductive season, both for males and females. Many Sorex species display a similar increase in home range size during the reproductive season (see Shillito, 1963a; Croin Michielsen, 1966; Pernetta, 1977), while Crocidura russula seems to have a constant home range size throughout the year (Genoud, 1981).

The activity pattern of $N$. fodiens did not vary seasonally. Similar stable activity patterns have been reported for Crocidura russula (Genoud \& Vogel, 1981) and Sorex coronatus (Genoud, 1984). High energy requirements probably cause the shrews to be as active in winter as in summer. During this latter season, energy requirements are probably less important and shrews spend more time in reproducitve activities.

\subsection{Time Budget}

Neomys fodiens, being active for 12 hours a day, is active to a greater extent than free-living Crocidura russula (almost 8 hours: Genoud \& Vogel, 1981) but less than Sorex coronatus (13 hours: Genoud, 1984) and S. araneus, S. arcticus and S. minutus (about 15 hours: Khlyap, 1980, 1983). Different energy requirements between the various species of Crocidurinae and Soricinae (Vogel, 1976; Genoud, 1985) probably explain the differences in the time budgets. None of these species had seasonal variations in their activity in the field. This fact differs from the observations of Buchalczyk (1972) who found a reduction in the activity patterns of captive water shrews during the autumn and winter. This difference may be explained by the regular food supply and the given, thermal conditions during the laboratory observations, as opposed to fluctuating field conditions.

\subsection{Activity Patterns}

The activity of $N$. fodiens was strongly concentrated in a few parts of its home ronge. Animals usually foraged in parts of the stream where the bottom was muddy. Movements between patches were rapid.

This behaviour, similar to that of Crocidura russula (Genoud, 1981), agrees with that predicted by Arditi \& Dacorogna (1985) where animals rapidly move through the poorest parts of their home range and stay for a long time in the richest ones. Animals stayed in these latter parts as long as the energy gains were higher than the costs of travelling to an' 
another place (MacArthur \& Pianka, 1966). In the present case, prey were approximately evenly distributed between the mud, stone and gravel bottoms of the study stream (Dupasquier \& Lardet, unpublished data). It is therefore likely that the concentrated activity of $N$. fodiens resulted from food accessibility. Since the duration of each dive is physiologically limited, water shrews have to concentrate their activity in portions of the stream where prey is easily caught.

\subsection{Home Range}

In the present study, home range size varied according to season. When the home range size for other insectivore species are compared the various methods used is often a limiting factor. For example, for $N$. fodiens, three different methods have been used to measure the home range: visual observations (Illing et al., 1981), trapping data with a particular CMR method of determing the home range size (Van Bemmel \& Voesenek, 1984), and radioactive tracking (present study). In addition to the different methods employed, the duration of observations also varied from 5 months (Illing et al., 1981), to 24 hours in the present case. Nevertheless, the results of these three studies give similar estimations of the home range size of $N$. fodiens: 60 to $80 \mathrm{~m}^{2}$ (Illing et al., 1981), $190 \mathrm{~m}^{2}$ (Van Bemmel \& Voesenek, 1984) and 106 to $207 \mathrm{~m}^{2}$ (this study).

Values in the present study were less than those obtained using the same method and for the same duration of time for other terrestrial srews: S. araneus (1600-2300 $\mathrm{m}^{2}$, Khlyap, 1983), S. coronatus (about $400 \mathrm{~m}^{2}$; Genoud, pers. comm.) or $S$. arcticus (1500-8400 $\mathrm{m}^{2}$; Khlyap, 1983). Values were similar to Crocidura russula $\left(102 \mathrm{~m}^{2}\right.$; Genoud, 1981). It appears that the semiaquatic nature of $N$. fodiens, living in a "onedimensional" environment, (the ecotone of the banks of the stream) influences the home range size.

The differences in the home range size of $N$. fodiens and the Sorex species may also be explained by the considerably higher energy requirements of the Sorex species (reviewed in Genoud, 1985). In spite of the their smaller weight, Sorex shrews have higher daily energy budgets than other shrews (see Gębczyńska \& Gębczyński, 1965 for N. fodiens, and Genoud, 1985, for a review). Therefore, the Sorex species need to cover larger home ranges in order to meet their requirements.

In conclusion, Neomys fodiens is a species having a particular foraging strategy. Nevertheless, $40 \%$ of the diet of $N$. fodiens and Sorex araneus is similar (Churchfield, 1984a). Foraging in water perhaps enables Neomys to reduce the competition with Sorex. For water shrews, the accessibility of aquatic prey is an important factor and explains the 
concentrated activity of the animals. Comparative studies between shrews would be of interest to determine why some mammal species evolved to a semiaquatic behaviour.

Acknowledgements: I would like to thank Prof. Vogel, director of the "Institut de Zoologie" of the University of Lausanne, who gave me the means to complete a $\mathrm{PhD}$. in his team. Dr. D. Stone read the manuscript and gave me many ideas to ameliorate it. Drs. R. Arditi and M. Genoud wrote the computer programme. Many members of the "Institut de Zoologie" helped me in the field work. This work was supported by a grant of the "Fonds National Suisse".

\section{REFERENCES}

1. Adams L. \& Davis S. D., 1967: The internal anatomy of home range. J. Mamm., 48: $529-536$.

2. Arditi R. \& Dacorogna B., 1985: Optimal foraging in nonpatchy habitats. I. Bounded one-dimensional resource. Math. Biosci., 76: 127-145.

3. Baar S. L. \& Fleharty E. D., 1976: A model of the daily energy budget and energy flow through a population of the white-footed mouse. Acta theriol., 21: $179-193$.

4. Buchalczyk A., 1972: Seasonal variation in the activity of shrews. Acta theriol., 17: $221-243$.

5. Churchfield S., 1984a: Dietary separation in three species of shrews inhabiting water-cress beds. J. Zool., Lond., 204: 211-228.

6. Churchfield S., 1984b: An investigation of the population ecology of syntopic shrews inhabiting water-cress beds. J. Zool., Lond., 204: 229-240.

7. Croin Michielsen N., 1966: Intraspecific and interspecific competition in the shrews Sorex araneus L. and S. minutus L. Arch. neerl. Zool., 17: 73-174.

8. Dehnel A., 1950: [Studies on the genus Neomys Kaup.]. Ann. Univ. M. CurieSklod. (Sect. C) 5: 1-63. [in Polish].

9. Don B. A. C. \& Rennolls K., 1983: A home range model incorporating biological attraction points. J. Anim. Ecol., 52: 69-82.

10. Gębczyńska Z. \& Gębczyński M., 1965: Oxygen consumption in two species of water-shrews. Acta theriol., 10: 209-214.

11. Genoud M., 1981: Contribution à l'étude de la stratégie énergétique et de la distribution écologique de Crocidura russula (Soricidae, Insectivora) en zone tempérée. Ph. D. Thesis, University of Lausanne.

12. Genoud M., 1984: Activity of Sorex coronatus (Insectivora, Soricidae) in the field. Z. Säugetierkunde, 49: $74-78$.

13. Genoud M., 1985: Ecological energetics of two European shrews: Crocidura russula and Sorex coronatus (Soricidae, Mammalia). J. Zool., Lond., 207: 63-85.

14. Genoud M. \& Vogel P., 1981: The activity of Crocidura russula (Insectivora, Soricidae) in the field and in captivity. Z. Säugetierkunde, 46: 222-232.

15. Illing K., Illing R. \& Kraft R., 1981: Freilandbeobachtungen zur Lebensweise und zum Revierverhalten der Europäischen Wasserspitzmaus, Neomys fodiens (Pennant, 1771). Zool. Beitr., 27: 109-122.

16. Khlyap L. A., 1980: [Shrews]: [In: "Theriological problems: Results of the marking experiments on mammals".] Akademya Nauk (USSR). Editions "Sciences", Moskva: 63-76. [in Russian]. 
17. Khlyap L. A., 1983: [Peculiarities of structure of home ranges and their use by shrews and forest voles.] Fauna Ecol. Rodents, 15: 162-203. [In Russian].

18. Lardet J.-P., 1987: Contribution à l'étude de quelques aspects de la strat'gie énergétique de la musaraigne aquatique, Neomys fodiens (Mammifères, Insectivores). Ph. D. thesis, University of Lausanne.

19. Lardet J.-P. \& P. Vogel. 1985: Evolution démographique d'une population de musaraignes aquatiques (Neomys fodiens) en Suisse Romande. Bull. Soc. Vaud. Sc. Nat., 368: 353-360.

20. MacArthur R. H. \& Pianka E. R., 1966: On optimal use of a patchy environment. Am. Nat., 100: 603-609.

21. Pernetta J. C., 1977: Population ecology of British shrews in grassland. Acta theriol., 22: 279-296.

22. Price M., 1953: The reproduction cycle of the water shrew Neomys fodiens bicolor. Proc. zool. Soc. Lond., 26: 189-207.

23. Ricci J. C. \& Vogel P., 1984: Nouvelle méthode d'étude en nature des relations spatiales et sociales chez Crocidura russula (Mammalia, Soricidae). Mammalia, 48: $281-286$.

24. Schloeth R., 1980: Freilandbeobachtung an der Wasserspitzmaus, Neomys fodiens (Pennant, 1771), im Schweizerischen Nationalpark. Rev. Suisse Zool, 87: $937-939$.

25. Shillito J. F., 1963a: Observations on the range and movements of a woodland population of the common shrew Sorex araneus L. Proc. zool. Soc. Lond., 140: 99-114.

26. Shillito J. F., 1963b: Field observations on the water shrew. Proc. zool. Soc. Lond., 140: $320-322$.

27. Sticke1 L. F,, 1954: A comparison of certain methods of measuring ranges of small mammals. J. Mamm., 35: 1-15.

28. Travis J,. 1982: A method for the statistical analysis of time-energy budget. Ecology, 63: 19-25.

29. Van Bemmel A. C. \& Voesenek, L. A. C. J., 1984: The home range of Neomys fodiens (Pennant, 1771) in the Netherlands. Lutra, 27: 148-153.

30. Van Winkle W., 1975: Comparison of several probalistic home range models. J. Wildl. Manag., 39: 118-123.

31. Vogel P., 1976: Energy consumption of European and African shrews, Acta theriol., 21: 195-206.

32. Weissenberger T., Righetti J.-F. \& Vogel P., 1983: Observations de populations marguées de la musaraigne aquatique Neomys fodiens (Insectivora, Mammália). Bull. Soc. Vaud. Sc. Nat, 364: $381-390$.

Received 27 August 1987, Accepted 30 December 1987. 


\section{Jean-Pierre LARDET}

UŻYTKOWANIE PRZESTRZENI I RYTM AKTYWNOSCI RZĘSORKA RZECZKA NEOMYS FODIENS W WARUNKACH NATURALNYCH

\section{Streszczenie}

Badano przemieszczenia, rytm aktywności i areały radioaktywnie znakowanych rzęsorków rzeczków Neomys fodiens (Pennant, 1771) w celu porównania ich parametrów ekologicznych z lądowymi gatunkami ryjówkowatych jak: Crocidura russula (Hermann, 1780) i Sorex coronatus Millet, 1828. Przeprowadzono 10 calodobowych obserwacji, od roku 1982 do 1985, w okresie od kwietnia do grudnia. Bez względu na porę roku rzęsorki były aktywne przez 12 godz./dobę (Tabela 1, Ryc. 1 i 2). Jest to więcej, niż u Crocidura russula, lecz mniej niż u Sorex coronatus. Różnice te wynikają prawdopodobnie z innego zapotrzebowania pokarmowego tych gatunków.

Rzęsorki poruszały się głównie wzdłuż strumienia, częściej w miejscach o błotnistym dnie (łatwiejszy dostęp do pokarmu), niż przy podłożu żwirowym (Ryc. 3). Od kwietnia do września areały samców wynosiły średnio $151 \pm 54 \mathrm{~m}^{2}$, a samic $263 \pm 93 \mathrm{~m}^{2}$ (Tabela 1). Cd października do grudnia areały były mniejsze (samce: $82 \pm 8 \mathrm{~m}^{2}$, samice: $129 \pm 61 \mathrm{~m}^{2}$ ). Wielkość areału rzęsorka rzeczka podobna jest jak u Crocidura russula, a mniejsza niż u Sorex coronatus. 